\title{
Evaluasi Bantuan Operasional Sekolah (BOS) Dalam Peningkatan Mutu Pendidikan di SMK Kristen BM Salatiga
}

\author{
Ari Setyoningsih*, Bambang Ismanto \\ Program Studi Pendidikan Ekonomi, Universitas Kristen Satya Wacana \\ *Corresponding Author. Email: 162017007@student.uksw.edu
}

\begin{abstract}
This reseach was conducted with the aim of seeking a information about the implementation of BOS and to obtain a gap in the implementation of BOS at the BM Salatiga Christian Vocational School in improving the quality of education. This study uses an evaluation model, namely the evaluation of gap in the implementation of a program. The subjects in this study were the principal, BOS treasurers, parents and students. Data collection techniques used were observation, interviews and documentation and later analyzed using the Miles and Hubermen model which included data reduction, presentation and then drawing conclusions. Based on the results of the study, it shows that there is still a gap between the implementation and the BOS standards at BM Salatiga Christian Vocational School. At the design stage, the implementation of BOS is in accordance with the BOS 2020 Technical Guidelines. At the installation stage there are still gaps, including when there is an urgent expenditure and while the expenditure must be based on the SPJ. At the stage of the process, There were also gaps, including the delay in disbursement of fuds, where BOS was the main source in implementing learning in schools so that it could be concluded that there was still a gap between the implementation of BOS and the Technical Guidelines.
\end{abstract}

\begin{abstract}
Abstrak: Penelitian ini dilaksanakan dengan tujuan untuk mencari informasi mengenai pelaksanaan BOS dan memperoleh suatu kesenjangan dalam pelaksanaan BOS di SMK Kristen BM Salatiga dalam peningkatan suatu mutu pendidikan. Penelitian ini menggunakan model evaluasi yaitu evaluasi kesenjangan dimana dalam penelitian ini menekankan pada adanya suatu kesenjangan di dalam pelaksanaan suatu program. Subjek dalam penelitian ini adalah kepala sekolah, bendahara BOS, orang tua dan siswa. Teknik pengumpulan data yang digunakan adalah observasi, wawancara dan dokumentasi selanjutnya dianalisis menggunakan model Miles dan Hubermen yang meliputi reduksi data, penyajian dan kemudian penarikan kesimpulan. Berdasarkan hasil penelitian menunjukkan bahwa masih terdapat kesenjangan antara pelaksanaan dan standar BOS di SMK Kristen BM Salatiga. Pada tahap desain, pelaksanaan BOS sudah Sesuai dengan Petunjuk Teknis BOS 2020. Pada tahap instalasi masih terdapat kesenjangan yang diantaranya adalah pada saat terdapat pengeluaran yang mendesak sedangkan pengeluaran harus berdasarkan pada SPJ. Pada tahapan proses terdapat juga kesenjangan yang diantaranya adalah pada keterlambatan pencairan dana, dimana BOS merupakan sumber utama dalam pelaksanaan pembelajaran di sekolah sehingga dapat disimpulkan bahwa masih terdapat kesenjangan antara pelaksanaan BOS dengan Petunjuk Teknis.
\end{abstract}

\section{Article History}

Received: 03-04-2021

Revised: 10-05-2021

Accepted: 19-05-2021

Published: 07-06-2021

\section{Key Words:}

Evaluation, BOS, Quality of Education.

\section{Sejarah Artikel \\ Diterima: 03-04-2021 \\ Direvisi: 10-05-2021 \\ Disetujui: 19-05-2021 \\ Diterbitkan: 07-06-2021}

\author{
Kata Kunci: \\ Evaluasi, BOS, Mutu \\ Pendidikan.
}

How to Cite: Setyoningsih, A., \& Ismanto, B. (2021). Evaluasi Bantuan Operasional Sekolah (BOS) Dalam Peningkatan Mutu Pendidikan di SMK Kristen BM Salatiga. Jurnal Kependidikan: Jurnal Hasil Penelitian dan Kajian Kepustakaan di Bidang Pendidikan, Pengajaran dan Pembelajaran, 7(2), 503-510. doi:https://doi.org/10.33394/jk.v7i2.3759 


\section{Pendahuluan}

Pendidikan merupakan suatu proses yang diarahkan dengan tujuan untuk memajukan potensi kepada peserta didik secara manusiawi sehingga nantinya akan menjadikan pribadi yang lebih unggul. Untuk mencapai hal tersebut, negara sebagai pemegang kekuasaan tertinggi mampu untuk menerapkan sistem pendidikan nasional yang nantinya dapat memberikan kehidupan bagi masyarakat yang semakin lebih baik. Peran pemerintah dalam pendidikan telah disebutkan pada UUD 1945 pasal 31 ayat 1 yang menjelaskan bahwa pemerintah memiliki kewajiban dalam membiayai pendidikan bagi warga negaranya. Sehingga dengan adanya hal ini dapat memperjelas bahwa pendidikan merupakan suatu hak bagi setiap warga negara. Oleh karena itu, pemerintah berupaya dalam meningkatkan mutu pendidikan.

Dalam upaya peningkatan mutu sekolah maka pelayanan yang diberikan harus sesuai dengan Standar Pelayanan Minimal (SPM) dan pelaksanaan pendidikan yang sesuai dimana dalam membiayai pendidikan pada zaman sekarang ini telah menjadikan permasalahan di masyarakat. Beberapa upaya yang telah dilakukan oleh pemerintah untuk mengatasi dan menjamin adanya suatu pembiayaan pendidikan yang telah dirasakan langsung oleh masyarakat. Hal ini dapat dilihat dengan adanya Peraturan Pemerintah Republik Indonesia Nomor 48 Tahun 2008 yang menjelaskan bahwa pembiayaan pendidikan merupakan tanggung jawab bersama pemerintah, pemerintah daerah dan juga masyarakat. Pemerintah yang dimaksud disini adalah pemerintahh pusat, pemerintah kota serta masyarakat yang ikut berpartisipasi dalam pembiayaan pendidikan, dengan hal ini sudah jelas bahwa pembiayaan pendidikan telah ditanggung pemerintah dan masyarakat. Salah satu pembiayaan pendidikan yang di tanggung oleh pemerintah adalah Bantuan Operasional Sekolah (BOS).

BOS merupakan program yang dibuat oleh pemerintah dengan tujuan untuk pembiayaan pendidikan bagi setiap siswa tanpa terkecuali. Pendanaan ini diharapkan mampu untuk meringankan biaya untuk penyelenggaraan kegiatan operasional sekolah. BOS digunakan dalam mengukur kualitas sistem pendidikan di Indonesia (Rosser \& Mohamad Fahmi, 2016). Anggaran BOS memiliki indikator yang harus dipatuhi dalam pencapaian Standar Pelayanan Minimal (SPM), SPM ini akan dilaporkan kepada Dinas Pendidikan. Pendidik memberikan dampak secara langsung dalam pengembangan diri serta mampu dalam mewujudkan tujuan pendidikan nasional (Slameto, 2012).

Bantuan Operasional Sekolah (BOS) dilaksanakan sesuai dengan Juknis BOS. Dana BOS yang diterima sekolah dihitung berdasarkan pada jumlah peserta didik, untuk Sekolah Menengah Kejuruan (SMK) sebesar Rp. 1.600.000 yang digunakan sebagai keperluan selama di sekolah. Penyaluran dana dibagi menjadi 3 kali selama satu tahun dimana pembagian dana yang dilakukan adalah 25\%, 50\% dan 25\%. Pada tahapan kedua lebih banyak karena pada tahap ini dana digunakan untuk pengadaan bahan baca siswa atau buku disekolah. Hal ini sejalan dengan penelitian yang berjudul "Analisis Pengelolaan Dana Bantuan Operasional Sekolah (BOS) di tahun 2017 di SMA Islam Dempo Timur Pasean Pamekasan" menyimpulkan bahwa pelaksanaan dana BOS penyaluran dananya setiap triwulan, pengambilan dana oleh bendahara dan kepala sekolah, penggunaan dana untuk kegiatan operasional sekolah non-personalia (Abdul Halik \& Nur Hidayati, 2018).

Berdasarkan hasil wawancara awal yang telah dilakukan dengan bendahara BOS di SMK Kristen BM Salatiga memberikan hasil bahwa pengelolaan BOS di SMK Kristen BM Salatiga sudah berjalan dengan baik, namun disisi lain juga mengalami hambatan yang diantaranya adalah keterlambatan pencairan dana sehingga untuk memenuhi kebutuhan 
sekolah sering terlambat. Hal ini sejalan dengan penelitian yang berjudul "Evaluasi BOS di Sekolah Dasar" yang menyimpulkan bahwa pada tahap pelaksanaan BOS di Sekolah Dasar (SD) terdapat kesenjangan yaitu adanya keterlambatan pencairan dana BOS dimana dana BOS ini merupakan sumber utama dari sekolah yang digunakan untuk melaksanakan pembiayaan pendidikan (Wahyu, 2020).

Penelitian ini bertujuan untuk menganalisis kecukupan dana BOS dalam peningkatan mutu pendidikan di SMK Kristen BM Salatiga. Kegiatan penelitian ini meliputi desain, instalasi, proses pelaksanaan, produk dan manfaat biaya. Dengan menggunakan penelitian evaluasi akan diketahui apakah ada kesenjangan yang terjadi berdasarkan pada analisis 5 komponen tersebut pada implementasi program BOS dalam rangka melihat peningkatan mutu khusus di SMK Kristen BM Salatiga.

\section{Metode Penelitian}

Penelitian ini merupakan penelitian evaluasi program. Model evaluasi yang digunakan adalah evaluasi kesenjangan (discrepancy) dimana di dalamnya lebih menekankan pada kesenjangan yang terjadi pada saat pelaksanaan program dengan standar yang ada (Wirawan, 2012). Tahapan dalam evaluasi kesenjangan ini diantaranya adalah desain, instalasi, proses, produk dan manfaat biaya. Penelitian ini merupakan jenis penelitian kualitatif dan teknik pengumpulan data dilakukan dengan observasi, wawancara dan dokumentasi. Subjek dalam penelitian ini adalah kepala sekolah, bendahara BOS, orang tua dan siswa.

Instrumen penelitian ini menggunakan panduan wawancara, lembar observasi dan lembar dokumentasi. Data yang telah dihasilkan kemudian akan dianalisis dengan teknik analisis data model Miles dan Hubermen, yang meliputi reduksi data, penyajian data dan kemudian penarikan kesimpulan. Penelitian ini menggunakan teknik triangulasi data yang meliputi wawancara, dokumentasi dan observasi (Sugiyono, 2018).

\section{Hasil Penelitian dan Pembahasan Evaluasi Desain Program BOS}

Tahap pertama dalam evaluasi kesenjangan ini adalah desain yang merupakan suatu evaluasi yang mencakup tentang pengertian, proses dan juga tujuan program. Berdasarkan hasil wawancara yang diperoleh didapatkan hasil bahwa:

"BOS adalah dana yang berasal dari pemerintah yang berguna untuk kelancaran pendidikan disekolah dimana tujuan dari BOS ini adalah untuk kelancaran pendidikan dan sasaran dari program ini adalah warga sekolah. Besarnya dana yang diterima siswa yaitu Rp. 1.600.000. dana ini merupakan dana yang penting bagi sekolah karena dana ini merupakan sumber utama dalam melaksanakan pendidikan. BOS memiliki keterkaitan dengan SPM dimana SPM ini dapat terpenuhi juga berasal dari BOS. Selain itu dapat ditunjang dengan kegiatan seperti ekstrakurikuler dan sebagainya".

Wirawan (2014) di dalam penelitiannya menjelaskan bahwa BOS dilaksanakan dengan tujuan untuk meringankan biaya pendidikan dan mendukung dengan adanya program pemerintah wajib belajar. BOS merupakan biaya yang dikeluarkan pemerintah dengan tujuan untuk menunjang pendidikan yang ada disekolah. Berdasarkan pada hasil wawancara yang telah dilakukan dapat memberikan hasil bahwa BOS merupakan dana yang berasal dari pemerintah sebagai pembiayaan pendidikan. BOS diupayakan mampu untuk mencukupi biaya yang diperlukan guna untuk meningkatkan mutu pendidikan. 
Sekolah memiliki berbagai jenis kegiatan yang bertujuan didalam peningkatan mutu suatu pendidikan. keterbatasan dana yang diberikan menyebabkan pihak sekolah mengalami kesulitan dalam merealisasikan anggaran BOS yang telah dibuat sebelumnya. Sehingga pihak sekolah juga menerima bantuan yang berasal dari orangtua dan bantuan ini bersifat sukarela (PP Nomor 48 tahun 2008).

Pada tahap ini sudah sesuai dengan juknis dan sekolah juga sudah memahami bahwa BOS tidak untuk bisa meningkatkan mutu pendidikan. Oleh karena itu, pihak sekolah harus mengelola dan juga memaksimalkan penggunaan BOS dan sekolah juga membuat program yang telah direncanakan sebelumnya.

\section{Evaluasi Instalasi Program BOS}

Pada tahapan ini, rancangan dilaksanakan sebagai standar di dalam mempertimbangkan langkah-langkah operasional dalam suatu produk. Berdasarkan hasil wawancara menunjukkan bahwa program sudah sesuai dengan keadaan sosial ekonomi yaitu warga sekolah. Rancangan BOS di SMK dilakukan dengan menyusun RKAS yaitu mengacu pada pemenuhan SPM dan juga SNP. Berdasarkan pada dokumen yang berkaitan dengan rencana yang dibuat sebelumnya bahwa RKAS dibuat bersama dan kemudian nantinya disahkan oleh kepala sekolah dan komite sekolah dalam bentuk pengawasan. Yang terlibat dalam pembuatan RKAS adalah kepala sekolah, bendahara BOS dan komite. Dimana komite nantinya berperan sebagai penanggungjawab. Hasil observasi dilakukan menunjukkan bahwa alokasi dana digunakan pada kegiatan operasional sekolah.

RKAS dibuat pada awal pembelajaran sehingga nantinya dapat terencana dengan baik dimana sebagai standar dalam melaksanakan program BOS. Hal ini bertujuan untuk mengevaluasi RKAS yang sebelumnya telah direncanakan dengan apa yang dilaksanakan sebelumnya yang selanjutnya pengawasan dilakukan pada saat menyesuaikan RKAS dengan program. Disisi lain SDM ini bertujuan untuk mendukung tercapainya suatu tujuan dan dapat dipertanggungjawabkan melalui SPJ.

Hal ini juga sama dengan kebijakan Edward (2012) yang menjelaskan bahwa faktor yang mempengaruhi suatu efektifitas kebijakan program adalah sumber daya dimana faktor ini diantaranya adalah kepala sekolah, bendahara BOS, orangtua dan siswa. selanjutnya komite sekolah sebagai penanggungjawan dan sudah sesuai dengan kualifikasi dalam pencapaian suatu SPM sekolah. Namun terdapat kesenjangan antara RKAS dengan pelaksanaannya. Kesenjangan ini bisa terjadi karena terdapat kegiatan yang mendesak dan kegiatan ini di prediksi pada awal pembuatan RKAS sehingga sekolah diharapkan mampu untuk menyesuaikannya dan selain itu juga terdapat kendala lain yaitu pada format laporan yang berbeda dan terkadang mengalami kesulitan dalam menyesuaikannya

\section{Evaluasi Proses Program BOS}

Prinsip pelaksanaan BOS di SMK ini sudah sesuai pada prinsip BOS yang mengutamakan keterbukaan terhadap warga sekolah yaitu dengan cara menempelkan pengunaan anggaran BOS di papan pengumuman yang ada disekolah. Berdasarkan dokumentasi yang ada, pemenuhan kebutuhan untuk SPM belum semuanya tercapai. Berdasarkan hasil wawancara yang dilakukan tentang ketepatan pada tahapan pencairan dana, pencairan dana ini pada akhir-akhir tahun ini mengalami keterlambatan dan tentunya hal ini berpengaruh pada kebutuhan sekolah. Orangtua atau wali siswa juga ikut serta di dalam melaksanakan program ini. Orang tua memberikan respon yang baik terhadap pelaksanaan program yang telah direncanakan oleh sekolah sehingga sekolah saat ini mengalami kemajuan juga didukung oleh semua waga sekolah. 
Pada tahapan ini membahas mengenai hasil BOS yang telah dilakukan di SMK Kristen BM Salatiga dimana dari hasil wawancara dapat diketahui bahwa banyak pencapaian pada bidang sarana dan prasarana dan juga pembelajaran yang didalamnya terdapat pencapaian prestasi pada bidang akademik maupun non akademik. Berdasarkan pada hasil wawancara yang dilakukan kepada kepala sekolah, bahwa SMK ini telah unggul pada bidang non akademik dan oleh karena itu sekolah berusaha meningkatkan prestasi pada bidang akademik. Tahapan ini tentang laporan pertanggungjawaban BOS dimana laporan dibuat setiap tiga bulan tentunya akan dievaluasi terlebih dahulu oleh kepala sekolah dan juga komite sekolah.

\section{Evaluasi Produk Program BOS}

Pada tahapan ini bisa dicapai dengan tujuan program dan tujuan ini harus berdasarkan pada juknis yang berlaku di tahun tersebut. Hal ini bisa dikatakan tercapai apabila tidak ada pungutan biaya pendidikan dan pendidikan menjadi lebih murah. Peningkatan mutu di SMK ini dapat dilihat dari banyakna prestasi yang diperoleh baik pada bidang akademik maupun non akademik. Selain itu terlihat pada pengembangan sarana dan prasarana yang ada disekolah. Tetapi pada pencapaian mutu pada SPM belum tercapai sepenuhnya dan ini masih diperhitungkan pada SPM yang ada disekolah.

Pada aspek kurikulum yang menyebutkan bahwa pemerintah memiliki rencana dan juga melaksanakan kegiatan ini membantu satuan pendidikan ternyata masih kurang dalam memenuhi SPM sehingga hal ini menyebabkan produk yang berkaitan dengan peningkatan mutu belum sesuai dengan standar. Berdasarkan hasil wawancara yang dilakukan dijelaskan bahwa banyak ketercapaian yang telah diperoleh pada sarana prasarana kemudian pada pengembangan fasilitas yang ada dan kegiatan lainnya. Berdasarkan pada hasil wawancara penelitian ini, kepala sekolah menyebutkan bahwa sebagian besar prestasi yang diraih ini adalah pada bidang non kependidikan atau non akademik dan untuk mengatasi hal tersebut sekolah berupaya untuk terus belajar meningkatkan prestasi pada bidang akademik. Evaluasi ini juga menjelaskan tentang laporan pertanggungjawaban dimana laporan ini dibuat setiap triwulan dan kemudian nantinya akan dievaluasi dan diawasi oleh komite. Pada kegiatan yang pembiayaannya berasal dari BOS di SMK Kristen BM Salatiga ini sudah baik.

\section{Evaluasi Analisis Biaya Manfaat Program BOS}

Pada tahapan ini akan menjelaskan tentang manfaat dan juga dampak yang ditimbulkan akibat adanya program ini. Dari hasil yang telah didapatkan dapat disimpulkan bahwa BOS bermanfaat. Hal ini bisa dilihat dari data yang diperoleh dimana didalamnya terdapat suatu pencapaian selama penerapan BOS ini dan juga sebagai penunjang tercapainya SPM ini tercapai. Dengan adanya program ini dapat meringankan beban orang tua. Manfaat ini sudah sesuai dengan prinsip pelaksanaan BOS yang di dalam pelaksanaanya sesuai dengan kenyataan dan dirasakan manfaatnya dan manfaat tersebut berguna untuk sekolah. Namun untuk saat ini berfokus pada pendidikan yang bermutu sehingga diperlukan suatu sosialisasi kepada orangtua.

Berdasarkan pada hasil wawancara yang telah dilakukan menyebutkan bahwa BOS sangat membantu orangtua dalam meringankan pembiayaan pedidikan yang ada disekolah. Manfaat ini juga sesuai dengan prinsip pelaksanaan program BOS dimana pelaksanaannya sesuai dengan tujuannya dan manfaatnya bisa dirasakan secara langsung oleh masyarakat. namun untuk saat ini masih berfokus dalam peningkatan SPM sehingga nantinya diperlukan sosialisasi bahwa fokus pengembangan pendidikan saat ini telah bergeser pada 
peningkatan mutu pendidikan. manfaat biaya ini sesuai dengan Permendiknas tentang SPM di Kabupaten/Kota. Dalam peraturan menegaskan bahwa suatu pembiayaan yang berkaitan dengan seluruh kegiatan yang mendukung pendidikan menjadi tanggung jawab dan juga merupakan tugas pemerintah. Manfaat biaya yang diterima oleh pihak sekolah diantaranya adalah bahwa sekolah mampu untuk memberikan honor pada pendidik dimana SMK Kristen BM Salatiga ini merupakan sekolah swasta, oleh karena itu honor pendidikan diambil dari dana BOS serta pembayaran SPP. Hal ini sesuai dengan penelitian yang berjudul "Evaluasi Bantuan Operasional Sekolah (BOS) di Sekolah Dasar" yang menyebutkan bahwa pendanaan untuk Guru Tidak Tetap (GTT) juga tercantum pada RKAS. Akan tetapi terdapat kesenjangan dalam peningkatan mutu yaitu tidak semua aspek pada BOS dapat terpenuhi (Rubiyati, 2020)

\section{Kesimpulan}

Berdasarkan hasil penelitian yang dilakukan bahwa BOS dalam pemenuhan SPM di SMK Kristen BM Salatiga terdapat kesenjangan antara standar dengan juknis BOS. Kesimpulan yang diperoleh berdasarkan pada tahapan evaluasi ini adalah:

1) Evaluasi Desain dalam pemenuhan kebutuhan SPM sudah sesuai dengan Juknis dimana didalamnya dijelaskan bahwa BOS merupakan sumber utama dalam pemenuhan suatu SPM.

2) Evaluasi insatalasi pada pemenuhan SPM masih terdapat kesenjangan dimana ketika ada kegiatan yang mendesak dan kegiatan tersebut tidak terencana pada RKAS sebelumnya. Selain itu juga terdapat kendala lain diantaranya adalah bahwa setiap tahun format RKAS selalu berbeda dan terkadang sekolah merasa kesulitan.

3) Evaluasi proses, pada tahapan ini SPM sekolah belum semuanya tercapai. Namun dengan adanya partisipasi masyarakat mampu untuk mencapai suatu program. Selain itu juga masih terdapat kesenjangan yaitu pada tahap pencairan dana BOS dimana pencairan dana BOS akhir-akhir ini mengalami keterlambatan. Oleh karena itu pihak sekolah meminjami uang untuk keperluan sekolah dan apabila dana BOS sudah cair di ganti.

4) Produk dalam BOS belum sesuai dengan Juknis. Ini bisa dilihat pada beberapa indikator SPM. Pencapaian yang telah dicapai pada SMK ini yaitu pada bidang sarana dan prasarana serta pada pembangunan fasilitas sekolah. Kemudian nantinya akan dibuat pada SPJ sebagai bagian dari implementasi pelaksanaan BOS di SMK Kristen BM Salatiga.

5) Pada evaluasi manfaat biaya sudah berjalan dengan baik dan sesuai dengan tujuan dan tentunya sudah terdapat pada juknis. BOS sangat bermanfaat bagi sekolah dan juga sekolah sebagai penunjang tercapainya SPM walaupun belum semua indikator pada SPM dapat tercapai.

\section{Saran}

Berdasarkan pada kesimpulan diatas, dapat disampaikan saran sebagai berikut:

1) Berdasarkan pada penelitian yang telah dilakukan pada tahap desain menunjukkan bahwa BOS sudah sesuai dan diharapkan mampu untuk mempertahankannya karena BOS merupakan sumber utama dalam pelaksanaan pembelajaran disekolah. 
2) Pada tahapan instalasi, sebaiknya sekolah diharapkan mampu untuk merencanakan sesuatu terlebih dahulu sebelum pembuatan RKAS sehingga nantinya tidak terjadi kesalahan dan penggunaannya sesuai dengan RKAS

3) Dalam evaluasi proses diharapkan untuk pihak pengawas lebih mengawasi pelaksanaan BOS ini. untuk keterlambatan pada pencairan dana sekolah sering terjadi dan sekolah harus meminjami terlebih dahulu dan apabila dana BOS sudah cair maka akan diganti.

4) Pada evaluasi produk ini belum sesuai, pemenuhan kebutuhan sekolah belum semuanya terpenuhi. Pencapaian yang telah dicapai adalah pada sarana dan prasarana. Selain itu juga pada kegiatan pembelajaran. pencapaian tersebut nantinya akan di laporkan pada laporan pertanggungjawaban BOS.

5) BOS memiliki manfaat yang luar biasa bagi sekolah karena BOS merupakan sumber dana utama dalam melaksanakan suatu pendidikan. Sehingga diharapkan bahwa program ini akan terus terlaksana sehingga membantu proses pembelajaran.

\section{Daftar Pustaka}

Ali, Mohammad dan Muhammad Asrori. (2014). Metodologi \& Aplikasi Riset Pendidikan. Jakarta: Bumi Aksara.

Arikunto, Suharsimi. (2014). Evaluasi Program Pendidikan: Pedoman Teoretis Praktis Bagi mahasiswa dan Praktisi Pendidikan. Jakarta: Bumi Aksara.

Arikunto, Suharsimi. (2010). Prosedur Penelitian: Suatu Pendekatan Praktek. Jakarta: PT Rineka Cipta.

Asnawi, Aulia Prihatin. (2013). Evaluasi Program Bantuan Operasional Sekolah (BOS) Dana Anggaran Pendapatan Belanja Negara (APBN) Tahun 2012 (Studi Pada Sekolah Menengah Pertama (SMP) Negeri 6 Kabupaten Bintan). Jurnal. Universitas Maritim Raja Haji Tanjung Pinang.

Badan Akreditasi Provinsi Sekolah/Madrasah Provinsi JawaTengah. http://bapsm.jatengprov.go.id/. Diakses tanggal 6 Januari 2018.

Gumono. (2010). Permasalahan Mutu Dalam Wajib Belajar Pendidikan Dasar 9 Tahun. https://gumonounib.wordpress.com/buku-elektronik/sastra/, diakses tanggal 5 Januari 2018.

Husein, T. (2017) Evaluasi Pelaksanaan Program Bantuan Operasional Sekolah (BOS) Dalam Upaya Mengurangi Angka Putus Sekolah. 13(9), 15.

Ismanto, Bambang (2016). Evaluation on financing Collaboration in Improving the Quality Of Primary Education, 12.

Ismanto, Bambang. (2014). Manajemen Pendanaan Pendidikan dalam Wajib Belajar 9 Tahun (Studi Kasus Pada SD Di Salatiga, Ungaran, Semarang, Demak, Kendal dan Purwodadi). Jurnal. UKSW Salatiga.

Latief, Abdul. 2011. Modul Evaluasi Program Pendidikan. Jakarta: Program Pascasarjana

Peraturan Menteri Pendidikan dan Kebudayaan Republik Indonesia Nomor 80 Tahun 2015. Petunjuk Teknis Penggunaan Dan Pertanggungjawaban Keuangan Dana Bantuan Operasional Sekolah Untuk Sekolah Dasar Dan Sekolah Menengah Pertama.

Peraturan Menteri Pendidikan Nasional Republik Indonesia Nomor 15 tahun 2010. Standar Pelayanan Minimal Pendidikan Dasar Di Kabupaten/Kota.

Pemerintah, P. (2013) Peraturan Pemerintah Nomor 32. Petunjuk Teknis Bantuan Operasional Sekolah tahun 2020. (2020) 
Priyanto, Andi. (2015). Pengoptimalan Standar Pelayanan Minimal untuk Memenuhi Standar Nasional Pendidikan Di Sekolah-Sekolah. https://www.kompasiana.com/andipriyanto/ pengoptimalan-standar-pelayanan-minimal-untuk-memenuhi-standarnasional-pendidikan-di-sekolah-sekolah. Diakses tanggal 5 Januari 2018.

Rubiyati, W., \& Ismanto, B. (2020). Evaluasi Program Bantuan Operasional Sekolah (BOS) di Sekolah Dasar. Jurnal Kependidikan: Jurnal Hasil Penelitian dan Kajian Kepustakaan di Bidang Pendidikan, Pengajaran dan Pembelajaran, 6(2), 220-229. doi:https://doi.org/10.33394/jk.v6i2.2614

Slameto, S. (2012). Monitoring Dan Evaluasi Program Bantuan Operasional Sekolah di Kota Salatiga Dengan Menggunakan Analisis Kesenjangan Tahun 2011/2012. Satya Widya, 28(1), 1. https://doi.org/10.24246/j.sw.2012.v28.il.pl-12

Sugiyono. (2010). Metode Penelitian Pendidikan. Bandung: Alfabeta.

Sugiyono, (2018). Metode Penelitian Manajemen: Pendekatan Kuantitatif, Kuantitatif, Kualitatif, kombinasi, Penelitian Tindakan Kelas dan Penelitian Evaluasi (Setiayawami (Ed): $6^{\text {th }}$ ed)

Suprobo, Stephanus Hari. (2012). Evaluasi Anggaran Dana Operasional Sekolah (BOS) Dalam Penciptaan Standar Pelayanan Minimal (SPM) Pendidikan Dasar Di Kabupaten Ogan Komering Ulu (OKU). Tesis. Universitas Gajah Mada.

UUD 1945. (1945). 4(1), 1-12. http://luk.tsipil.ugm.ac.id/atur/UUD1945.pdf

Wirawan. (2012). Evaluasi Teori, Model, Standar, Aplikasi, dan Profesi (E.T.Tantra (Ed): $2^{\text {nd }}$ ed). Jakarta: Rajagravindo Persada.

Wirawan, M. (2014). Evaluasi Kebijakan Dana Bantuan Operasional Sekolah Dalam Peningkatan Mutu Pendidikan (Studi Pada Sekolah Dasar Negeri Percobaan 1 Kota Malang). Jurnal Administrasi Publik Mahasiswa Universitas Brawijaya, 13(1), 12-15 